\title{
はりと柱の接合部における高強度異形鉄筋の 通し鉄筋の定着に関する研究
}

\author{
正会員 ○小倉弘一 郎* 同 亀田 登与三郎**
}

1. まえがき 鉄筋コンクリート構造の中間柱と大ば りの接合部では左右のはりの鉄筋を通して柱巾に定着す る事が多いが、ての短い定着長さ内での地震応力時の定 着の是非が問題とされている。てれに関しては、坪井、 八代両博士による一連の研究1》があるが、筆者はとくに 最近その利用が盛んになって来だ高強度異形鉄筋につい て、短い柱巾で定着が十分か否かを実験的に研究した。

2. 実験の概要 試験体は第 1 図に示すような接合部 を対象とした小試験体で、はり鉄筋には上下各々1-13 を用い $\left(p_{t}=p_{c} \doteqdot 1.5 \%\right)$ 、柱巾すなわち定着さを $l=20$ $d, 30 d$ とした。定着部に長期許容付着応力の約 2 倍 （第 1 荷重階）および 3 倍(第 2 荷重階)の応力が生ずるよ うな曲げモーメントをおのおの正方向および正負方向に 3 回ずつはりの固定端に加兑てゆき、最後に正方向に破 壊させた。はり固定端の回転角を柱面から $5 \mathrm{~cm}$ 区間の 検長でダイヤルゲージで測定した。荷重は大野和男博士 提案のせん断加力法に準して加えている。

鉄筋には、高強度 異形鉄筋としてはドイツ製品の Rippen Torstahl (TRR),比較のための丸鋼としてSS 39 を用い（第1 表)、コンクリートには $F_{c} \doteqdot 180 \mathrm{~kg} / \mathrm{cm}^{2}$ の 普通コンクリートを用いた。武験体の種別は第 2 表 1 ,
第 1 表 使用鉄筋

\begin{tabular}{|c|c|c|c|c|}
\hline & & $\sigma_{y} \mathrm{t} / \mathrm{cm}^{2}$ & $\sigma_{B} \mathrm{t} / \mathrm{cm}^{2}$ & 伸び\% \\
\hline 鋼 & S S 39 & 2690 & 4060 & 34 \\
\hline 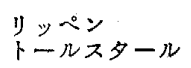 & TRR & $4190^{*}$ & 5095 & 8 \\
\hline
\end{tabular}

の定着で十分のようである。

（2）はり固定端の回転角は初期の応力より計算値をは るかに上廻る。鉄筋降伏理論モーメント時の回転角実験 值 $\theta_{E}$ 之、弹性計算值 $\theta_{T}=\frac{M_{Y}}{E I}\left(E=2.1 \times 10^{5} \mathrm{~kg} / \mathrm{cm}^{2}\right.$, $\left.I=\frac{1}{12} b D^{3}\right)$ の比は、SS 39の場合で約 8 倍、TRRで約 6 倍となる。各々については、 $l=20 d, 30 d$ の間の $\theta_{E}$ の差は僅かである。

（3）はり固定端の回転角が大きいのは、柱巾の中の鉄 筋の伸びとすべりが、はり端に伸びだしてくるためであ る。鉄筋降伏時において、実験值 $\theta_{E}$ と、柱中の鉄筋の 伸びだしを考学ない $e$ 函数法によるはり端回転角 $\theta_{T^{\prime}}$ と の差から、柱中の鉄筋の平均歪 $\epsilon_{t m}$ （すべりも含む見か けの值）を求めると第 2 表 11 項となる。SS 39 では、 かなり柱中で滑りと伸びがあるが、TRR ではその量が 非常に少なく、滑りの点汃ら TRR は柱巾 $20 d$ の定着 で十分のように考杂られる。
2,3 項任示夺。各種 2 個ずつで ある。TRR $20 d-0$ は、柱巾の 中で、鉄筋にビニールスリーブ をかぶせ、鉄筋の付着力を完全 にのぞいたものである。

\section{3. 実験結果の総括 実験結}

果を第 2 表に示す。本実験は試 験数も少なく予備実験のはんい をでないが、主要な結果をのべ るとつぎのようである。

(1) SS 39, TRR とも、柱币 を $20 d$ とってけば、かなりの 高応力の数回の繰返し荷重の後 でも、はり端は鉄筋の降伏によ って耐力がきまり、実験值は理 論值をかなり大巾に超えてお り、耐力の点汃らは、柱巾 $20 d$

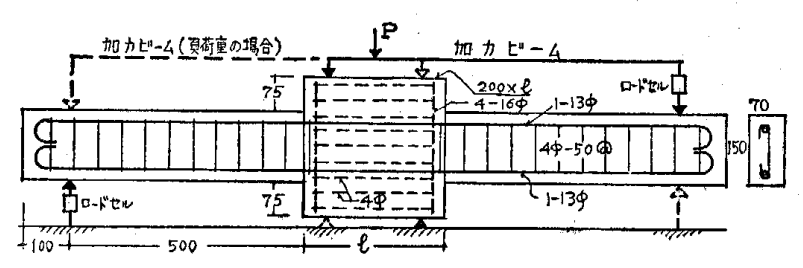

第 1 図試験体形状寸法

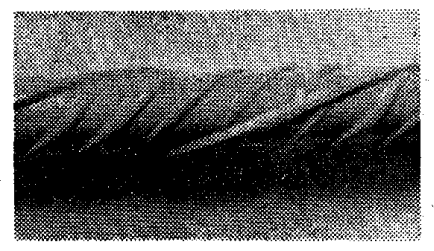

第 2 図リッペントールスタール 果

\begin{tabular}{|c|c|c|c|c|c|c|c|c|c|c|c|}
\hline 1 & $\overline{2}$ & $\overline{3}$ & 4 & 5 & 6 & 7 & 8 & 9 & 10 & 11 & 12 \\
\hline 鉄筋 & $\begin{array}{c}\text { 柱巾 } \\
\iota\end{array}$ & 加力法 & 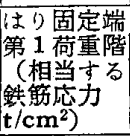 & 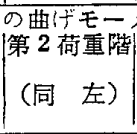 & $\begin{array}{l}\text { xント } \\
\text { 最大何 } \\
\text { 重時 } \\
M_{u}\end{array}$ & $\begin{array}{l}t \cdot \mathbf{c m}) \\
\boldsymbol{M}_{u} \text { の } \\
\text { 理論值 }\end{array}$ & 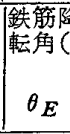 & $\begin{array}{l}\text { E時の } \\
10^{-5} \mathrm{Cr} \\
\theta_{T}\end{array}$ & 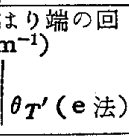 & $\begin{array}{l}\text { 柱中の鉄筋 } \\
\text { 小平均歪 } \\
\varepsilon_{t m} \\
\times 10^{-2}\end{array}$ & $\begin{array}{c}\text { 鉄筋の降优 } \\
\varepsilon_{Y} \varepsilon_{Y} \\
\times 10^{-2}\end{array}$ \\
\hline$S \leq 30$ & $20 d$ & $\begin{array}{l}\text { 正 方 } \\
\text { 正負方向 }\end{array}$ & $\begin{array}{c}0 \sim 16 \\
(1.15) \\
\pm 16(1.15) \\
\end{array}$ & $\begin{array}{c}0 \sim 24 \\
(1.73) \\
\pm 24(1.73)\end{array}$ & $\begin{array}{l}48 \\
47\end{array}$ & $\begin{array}{l}39 \\
39\end{array}$ & $\begin{array}{l}58 \\
76\end{array}$ & $\begin{array}{l}8.9 \\
8.9 \\
\end{array}$ & $\begin{array}{l}18 \\
18 \\
\end{array}$ & 0.127 & 0.128 \\
\hline & $30 d$ & 正負方向 & $\pm 24(1.73)$ & $\pm 36(2.60)$ & 51.5 & 39 & 73 & 8.9 & 18 & 0.089 & 0.128 \\
\hline \multirow{3}{*}{ TRR } & $20 d$ & $\begin{array}{l}\text { 正 方向 } \\
\text { 正負方向 }\end{array}$ & $\begin{array}{c}0 \sim 28 \\
(2.02) \\
\pm 28(2.02) \\
\end{array}$ & $\begin{array}{c}0 \sim 42 \\
(3.03) \\
+42(3.03) \\
\end{array}$ & \begin{tabular}{l|}
79.5 \\
76
\end{tabular} & $\begin{array}{l}57 \\
57 \\
\end{array}$ & $\begin{array}{l}80 \\
78 \\
\end{array}$ & $\begin{array}{l}13.1 \\
13.1 \\
\end{array}$ & $\begin{array}{l}55 \\
55 \\
\end{array}$ & 0.065 & 0.400 \\
\hline & $30 d$ & 正負方向 & $\pm 42(3.03)$ & $\pm 63(4.55)$ & 57 & 57 & 84 & 13.1 & 55 & 0.051 & 0.400 \\
\hline & $20 d-0$ & 正方向 & pass & pass & 53 & 35 & 226 & - & - & - & - \\
\hline
\end{tabular}

(4) SS 39,TRR の何れの場合も、正方向之正負方向の 繰返しに関して耐力、剛性の差はほとんど認められない。 本研究は八幡製鉄株式会社委託研究費によって行った。

1）坪井善勝、八代秀雄；仕口に括ける鉄筋の付着に関する 実験的研究 (RC架構接合部に関する研究15報); 建築学 会論文報告集57号

* 明大工学部 教授 工博 ** 明大工学部 助手 